\title{
Shonen Kurabu and the Japanese Attitude Toward War
}

\author{
Gijae Seo ${ }^{1}$
}

Published online: 6 March 2020

(c) The Author(s) 2020

\begin{abstract}
The Japanese people's understanding of the Fifteen Years War (1931-1945) is still problematic. The problem of the war was commonly solved by transferring responsibility for the war to an obscure subject called the State, and by offering financial compensation to those who were directly affected. However, there has been no in-depth discussion of how the Japanese public's understanding of the war in the period before defeat was modified in the post-war period. This article is a study of the children's magazine Shonen Kurabu, which gained wide popularity by featuring articles related to war during the early modern era of Japan, including the wartime period, and continued to be published until 1962. By focusing on Shonen Kurabu, this paper explores the close relationship between the mass media and the public attitude toward war, and the handling of the theme of war by both the media and the public.
\end{abstract}

Keywords Shonen kurabu $\cdot$ Media $\cdot$ Japan $\cdot$ War $\cdot$ Public attitudes

\section{Introduction}

World War II ended with the defeat of Germany and Japan. The processing of defeat is always complicated and difficult, but it is especially so for nations that, as well as suffering greatly, were and are widely regarded as having been the aggressors

\footnotetext{
Gijae Seo is a $\mathrm{PhD}$ who majored in Japanese literature and culture in the early modern period. She works as an Assistant Professor in the Department of Center for Asia and Diaspora, Konkuk University, Seoul, Korea. She is currently working on Japanese children's literature on war and has written a book titled Shikata Shin and Children's Literature on War (2017), which analyzes the works of Shikata Shin, a children's literary writer who returned from a Japanese colony following the end of the war. This work was supported by the Ministry of Education of the Republic of Korea and the National Research Foundation of Korea (NRF-2017S1A5A2A01023716) and this paper was supported by the KU Research Professor Program of Konkuk University.
}

Gijae Seo

seogijae@hanmail.net

1 Department of the Center for Asia and Diaspora, Konkuk University, 1205 A New Millenium Building, 120, Neungdong-ro, Gwangjin-gu, Seoul 05029, Republic of Korea 
in the conflict and responsible for atrocities committed against others. The contrast between the ways in which the two countries responded is illuminating. After World War II, Germany and Japan followed a similar path in many respects: in both, there were military trials held for war criminals, economic revival from ruin and chaos, high economic growth, and the rise from economic power toward political power. However, in the matter of war responsibility the two nations have shown contrasting attitudes. In order to help understand the elements of denial and defensiveness in the Japanese response, this article will analyse how the Japanese reaction to defeat in World War II was mediated to Japanese children during and after the war through Shonen Kurabu, which was an influential and well-known magazine until the midtwentieth century.

Not long after the end of the war, the German philosopher Karl Jaspers argued that the Nazi leaders and activists should take criminal and political responsibility for the atrocities committed during the war, but in addition he pointed out the public's responsibility for looking on and their tacit alignment with the barbarity of war (Jaspers 1998). Of course, this was not readily accepted by the German people. Ralph Giordano referred to this post-war psychological resistance and denial of responsibility as the "second fault," and the eventual public consensus upon the topic led Germany to become a "society of responsibility." (Giordano, 2005).

In Japan, however, many people have not shown any regret over the war itself, let alone for the "second fault" after the defeat (Yukio Mochida, 1994). Kojin Karatani points out that Japan has had scholars in the mould of Karl Jaspers (Tanabe, 1948), but their influence has been limited because of the lack of inquiry into the causes of the war (Karatani, 2012, p. 142).

Of course, there has been a place for regret in Japanese society. In 1950s, there was the rise of left-wing parties and groups against rearmament and security, embracing antimilitarism and pacifism. The pacifist movement extended to a protest against the U.S. bases in Japan, a movement against the atomic bomb and a constitutional movement. Moreover, they opposed overseas deployment of the Japan SelfDefence Forces, and economic revival through military industrialisation (Tanaka 2000, p.14-15).

Despite these facts, the Japanese pacifist movement is strongly related to the national ideology of victimhood. They regarded themselves as victims of war because World War II ended soon after the nuclear bombing in 1945 and Japan was in the hands of the occupation forces' General Headquarters (GHQ). In 1960s, the armament of Japan had been restructured against the background of the Cold War. Fusao Hayashi supported the Great East Asia War in Chuokoron in 1962, and in 1966 the Finance Ministry published "A desirable image of a person" as a part of child educational policy, in which a good person was described as one who gives their fealty to the nation and respects the Japanese Emperor (Shibuya, 1983, p.154). In this way, the tendency to distort Japanese experiences and memories of war accompanied the rise of a new conservatism in Japan (Tsuboi, 2005, p.12).

Today in Japan, the problem of war responsibility continues to be further diluted, with many people refusing to accept their country's responsibility for the war, which has led to political conflicts with the nations that were formerly its colonies. From the late 1990s, there was an increase in small group meetings 
of historical revisionists questioning Japan's supposedly masochistic view of history. It was a tumultuous period for Japan: the movement occurred in the context of Japan's economic bubble, the Great Hanshin Earthquake, the Aum Shinrikyo incident, bureaucratic corruption and university reforms. The Japanese Society for History Textbook Reform argued that Japanese responsibility for war was overemphasized (Yi, 2016, pp. 45-72). Furthermore, they defined their neighbour countries as enemies over the issues of Japanese history, the abductions of Japanese citizens by North Korea and the territorial disputes in the 2000s. The tendency has been continued by Netouyo (online right-wingers).

Although responsibility for war is regularly mentioned in Japan, it is hardly perceived as an important issue among the general public. This attitude began to take shape during the war itself and after the ceasefire. In order to understand what war meant to the Japanese public during this period, this study focuses on the mass media that were popular among the public during the war. In particular, it explores Shonen Kurabu (少年俱楽部, Boy's Club), a children's magazine that influenced not only adults and parents, but also the children of the Japanese archipelago and colonies. Kodansha, a major publishing house in Japan, published the magazine.

As shown by Kenichi Kato (1964), Nobuhisa Matsudaira (1986), Koichi Sato (1987), Kojiro Sakamoto (1989), Houe Hujisawa (1997), and Michimasa Saito (2015), the magazine had a strong tendency to emphasize nostalgia during the Fifteen Years War (1931-1945). The magazine has been referred to as an important coping mechanism for those who grew up at that time, especially boys, as a way to endure the hardships of war. On the other hand, the contribution of the magazine to Japanese imperialism has been discussed in research by Tadao Sato (1959), Hiroshi Sunada (1976), Toshio Tsuzukibashi (1997), and Masakatsu Uchida (2012). Christa Kamenetsky has shown how the Nazi regime inspected and censored children's books to promote National Socialism and argues that it took advantage of traditional literature to manipulate the spirit of children in Germany. Recent studies of Shonen Kurabu show that it too influenced the development of children's thinking. Karl Ian Uy and Cheng Chua illustrate the dominant position of Japanese literature during the period of imperialism, taking the example of the depiction of the Chinese and South Pacific islanders as savages (Uy \& Cheng Chua, 2016). In addition, Hyunjung Han has explored the geographical imagination of Japanese and Korean children and their differences through a comparison of the adventure stories in Shonen Kurabu and in Orini, a Korean magazine (Han, 2016). The study concludes that Shonen Kurabu was a loyal vassal in extending imperialism, but omits to explain in detail how the war and the readers related to each other and how the Japanese attitude toward war was developed.

This study will use Shonen Kurabu, which was published in a time of change during and after World War II, to examine the depiction of war and the attitudes shown both before and after defeat, as well as the responses of the magazine's young readers. In this way, we can examine Japanese perceptions of war and the origins of the public presentation of the Japanese as victims, which is strongly connected to the current understanding of war in Japan. 


\section{Why Analyze Shonen Kurabu? A Pathway to Understanding the Public}

Shonen Kurabu was founded in 1914 and was published until 1962. It was a latecomer compared to other children's magazines, such as Shonen Sekai (Hakubunkan), first published in 1895, and Nippon Shonen (Jitsugyo no Nihon Sha), which first appeared in 1906. Those two magazines discontinued publication in 1935 and 1938 respectively. It was a leader among children's magazines until Japan's defeat in the war. Shonen Kurabu sold 750,000 copies in 1935. The cover of Shonen Kurabu often featured a color scheme of intense red, a boy in military uniform or a smiling boy in school uniform hoisting the Japanese national flag, and literary works featuring brave children with intrepid spirits venturing forth on the Asian continent. The popularity of Shonen Kurabu is confirmed by the greater circulation of Shonen Kurabu compared to that of the literary magazine for children, Akaitori, which featured sensitive, good-hearted children of the petit bourgeoisie, but sold only about 30,000 copies at its peak (Kawahara, 2007, pp. 111-116).

In the early period of the magazine, Shonen Kurabu focused on people's lives and children's education. Later, it gained popularity and found success in military adventure fiction during the end of the Taisho and the early Showa eras (Iwahashi, 1988, p. 9). The magazine was targeted at the older primary school and middle school students (Tanaka, 2013, p. 122), a stage of development believed to be a time of heightened self-consciousness in which adolescents think over their future and can be influenced by their parents and teachers. Kenichi Kato, the editor prior to Japan's defeat, recalled the heyday of the magazine, saying: "More important than the circulation size is how the magazine affected readers in the formation of their character" (Kato, 1966a, p. 1). The magazine was called the home of the heart of modern readers (Kato 1968, p. 128). According to Kato, it owed its tremendous influence on children to the many writings it published with the purpose of cultivating virtue, in a way boys liked. When delivered to a home, it was circulated to family and friends. Kato estimates, "Five million copies were published a year. If a copy was read by five readers, that would be 25 million people reading the magazine annually" (Kato, 1966b, p. 1011). Nowadays, the Internet and broadcasting media are closer to the public; however, magazines were a cutting-edge form of easily accessible media at that time. It was also a forum that reflected and generated a common consciousness in the public, since the publishers' choices were largely determined by their perception of what would be popular with their readers and improve sales. When the magazine was at its peak, the participation of the number of readers was so great that the editorial department alone could not handle it. A fandom was formed at around this point.

First, it was parents who recommended the magazine. They were the most likely to fund their children's subscriptions. They also became involved in the fandom by praising the magazine or contributing articles for publication (Shonen Kurabu February, 1930, p. 267). In addition, schoolteachers advised students to bring the maps in the magazine to school because they made good learning materials (Shonen Kurabu August, 1933, p. 309). Schools even recommended groups of people to purchase the magazine. Moreover, the staff of the magazine might visit a school (Kato, 
Fig. 1 A cover of Sonyen, Korean children's magazine during the Japanese forced occupation. Sonyen, April 1937 Cover

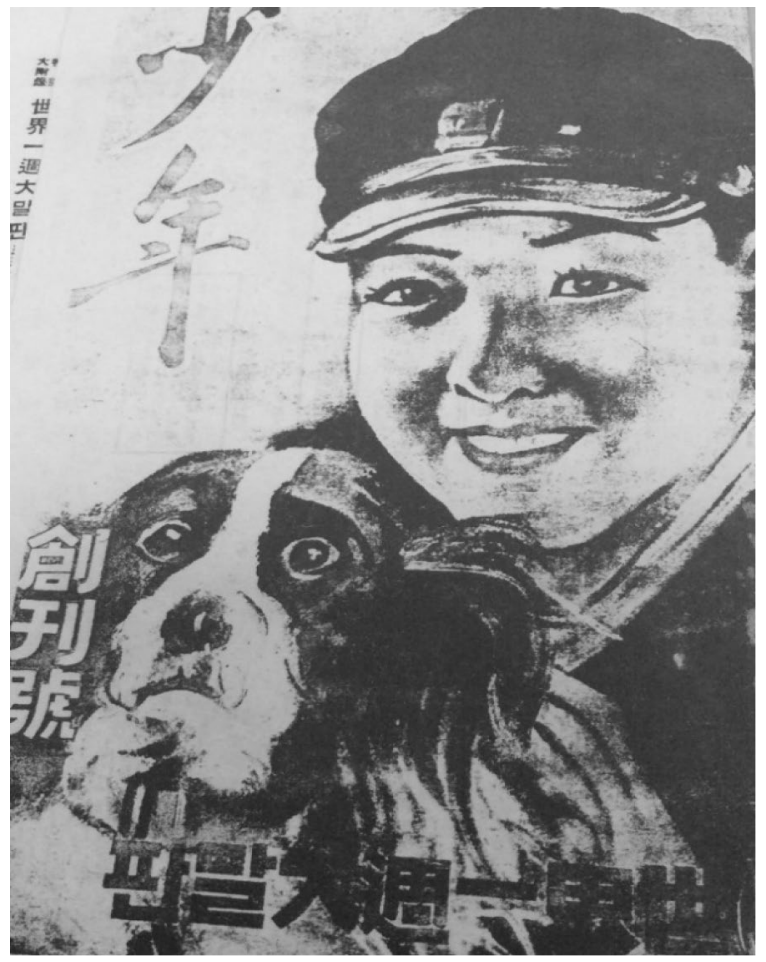

1968 , p. 124) and interact with their readers by performing drama, showing movies, having a signing event and giving talks (Shonen Kurabu May, 1938, p. 409).

The magazine also provided schools with an opportunity to hold writing contests on selected topics, such as "praise of Japan's colonisation of Korea," and awarded a prize to winners. Competition between schools was encouraged and the names of the winners and their schools listed in the magazine. Accordingly, Shonen Kurabu had a close relationship with teachers. Many former teachers worked for the magazine, and editors with teaching backgrounds played an important role in fulfilling the needs of the schools and children, based on national policy and the demands of the family. Interestingly, the magazine was also recommended by some employers for their young workers who had given up further study and instead chosen to work (Shonen Kurabu, February, 1930, p. 267). This indicates that fandom came from a wide range of age groups. Shonen Kurabu greatly influenced people beyond the Japanese archipelago, such as in the colonies of Joseon (Korea), Taiwan, Manchuria, and Sakhalin. There was even a similar magazine in Korea during the colonial period (Fig. 1). ${ }^{1}$ Superficially, there appears to be no close link between war and

\footnotetext{
1 A magazine called Sonyen (Boys), the Company of Chosun Ilbo, from April 1937 to Dec. 1940), published in Korean in colonial Korea, imitated Shonen Kurabu in many ways: the layout of the cover, the intent of the magazine (being a useful and interesting magazine for children), the contents (literary works, a section for boys' participation, advertising, the promotion of public opinion in favor of imperialism), the monthly publication, the target readers' age, praise from surrounding adults, the close link
} 
children; after all, it is difficult for children to actually engage in war. However, the Japanese government considered that children needed to develop the concept of war early as possible. It was a national demand in that they needed loyal subjects who would serve the Japanese Emperor and the Japanese way of life as well.

The ways in which Shonen Kurabu found channels to communicate with and attract children were very elaborate and ingenious. The editorial department did not forcibly instill ideas and ideologies into children, but framed a way for children themselves to discover and learn from the magazine. The covers which pictured boys smiling with confidence incited readers to identify themselves with the boys depicted, prompting them to take on the heroic image as their own. Moreover, the magazine illustrated the idea that a man should be strong and active in carrying out his duty with self-motivation rather than being directed by others. The messages presented in the magazine, such as putting effort into studying at school, growing in knowledge and skills and being a person of dignity with strong mentality, are powerful. One more thing added to this is a spirit of joy. The magazine excludes sadness and depression from its writings, even ones about war and the death of soldiers. At the peak of its popularity, its main themes evoked gaiety and excitement. They were critical elements in holding up Shonen Kurabu. Due to its uplifting stories, many recalled it as a crutch during the tough times.

Since children could not take part in the war because of their young age, there was a need for a tool to help them experience war without actual participation. Children could prepare themselves as soldiers for the future through the romanticizing of war. Through such efforts, war could be transformed into something that could inspire them with cheer and excitement. To achieve this, the editors took active advantage of adventure stories, comic strips (linked to the element of fun), appendices (maps, pictures, photographs of the Emperor, descriptions of models of weapon), and information on advanced weapons such as airplanes and aircraft carriers. Unlike conventional literary magazines, which only had incidental illustrations, Shonen Kurabu established the distinction of being vivid and dynamic. It functioned as a magazine for reading, seeing, touching, and talking - a magazine that would help readers to practice for a future reality. At the end of war, children even went so far as to regard their very bodies as weapons.

\section{Shonen Kurabu Immediately Before and After the Defeat}

After the war ended, the publishing industry of Japan was faced with the problem of "responsibility." On January 24, 1946, the "Special Committee for the Autonomous Purge of the Industry on War Responsibility" was established, based on the resolution of the Extraordinary General Meeting of the Japan Publishing Association. Kodansha was also one of the publishers that had to bear responsibility for the war.

Footnote 1 (continued)

between the editorial staff and children, the solidarity of children, the sales strategy, and so on. The editors of the magazine also consisted of people who had studied in Japan (Seo, 2018b, p. 217). 
Fig. 2 "Preparations for Unfailing Victory." Shonen Kurabu, January 1945, cover

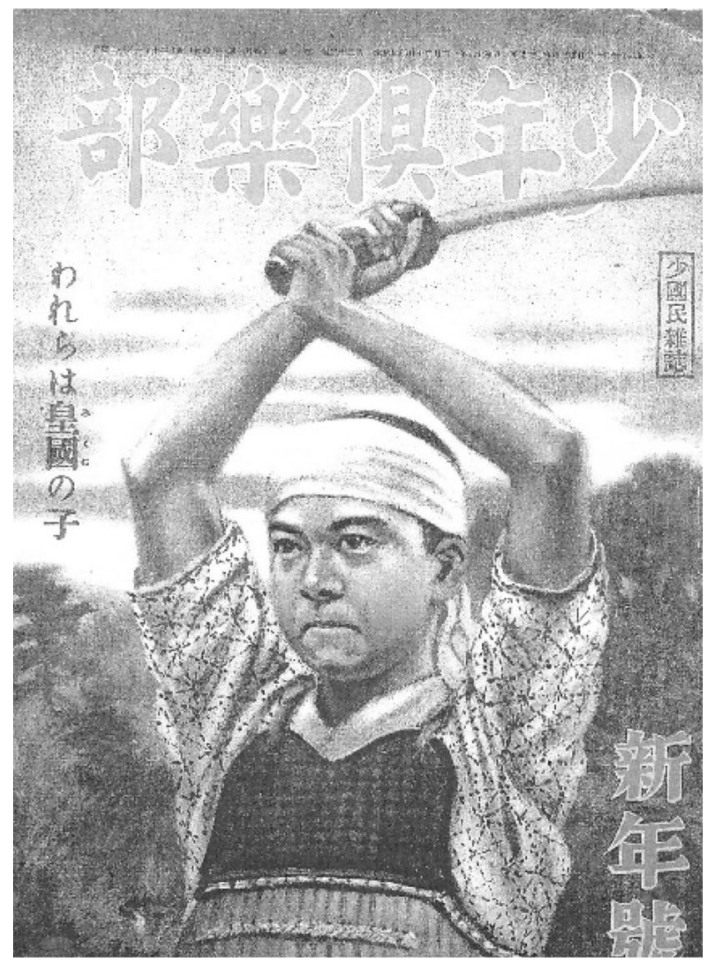

Kodansha, the publisher of Shonen Kurabu, was informed by the Special Committee of the following decisions: "You should confine your capital to publishing, and limit the shares held by the Noma family to $30 \%$ or less. You should turn the company into a thoroughly democratic organization, renovate the editing department, and limit the publishing business to sections on boys, women, the public, entertainment, and philosophy" (Yamanaka, 2013, pp. 21-22). The issue of responsibility for facilitating jingoism does not appear here. Shonen Kurabu continued to be published with no change of its identity, only reducing the business in size. Soon after the defeat, the Association of Writers of Japanese Children's Literature declared that they would not write for Kodansha. However, this determination did not last.

Figure 2 shows the cover of the New Year's issue of 1945. Just as in the previous issues, the color cover depicts the torso of a kendo boy who appears prepared to fight, with confidence in his eyes. The cover of Shonen Kurabu always had the face of a boy, accompanied with phrases suggesting resolution. The magazine was reduced to less than 70 pages by the end of the war due to material shortages, but, beginning with the photograph of the Emperor saluting on a horse, the contents of the magazine pointed in the single direction of the boy as the subject of war victory: a letter from the battlefield, news of the Kamikaze Commandos, an article on air resistance in relation to the speed of a fighter plane, the oath of a boy industrial warrior, comic strips depicting the delivery of gifts to soldiers, a 
Fig. 3 "Trample them to death" Shonen Kurabu March/April 1945 , p. 17

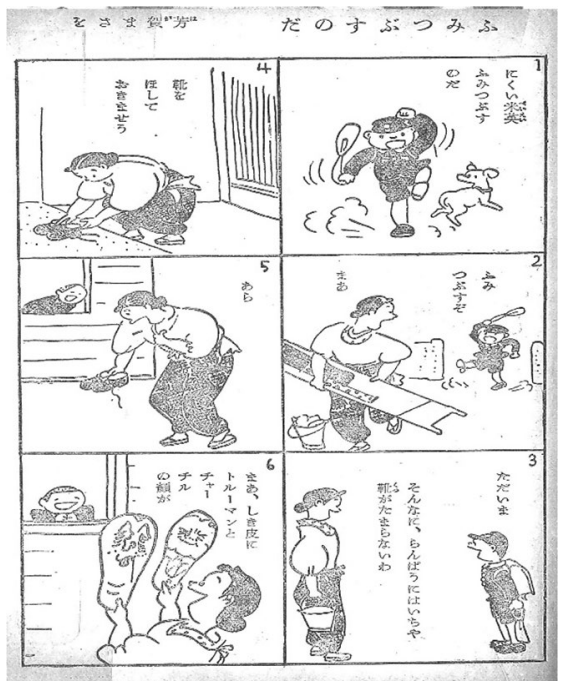

notice about the writing contest dedicated to the souls enshrined in the Yasukuni Shrine. In particular, the article "I make a solemn vow in the New Year of victory" introduced the saying of Second Lieutenant Masaaki Kubo of the Banda Flying Corps of Special Attack Unit, when he made a sortie: "Boys of the Divine Nation of Japan. This is the very year of the victory in the Great East Asia War. We will win the war without fail. We must win the war and allow the Emperor's heart to rest in peace" (Shonen Kurabu January, 1945, p. 44). In addition, the magazine printed poems written by soldiers before mission flights, which depicted their yearning for their parents and reflected on the glory of the Emperor before imminent death (Shonen Kurabu January 1945, p. 32). The poems were about the Kamikaze Commandos, that is, the youths who turned their own bodies into weapons.

Shonen Kurabu emphasizes the noble spirit of the Japanese people throughout history, and recommends that the boys unite with the planes to jump into the battlefield. There is also a section titled "Let's Know Military Terminology Correctly" that lists and explains all the terms related to fighter aircraft. The editorial news of the March/April issue of 1945 states:

Probably at school, the factory, or at home you may have heard of stories of One person kills ten people and One person kills one hundred people. Soldiers struggling in the island of Luzon, soldiers battling in Burma, and soldiers advancing to the continent of China-all of them are crushing the army of Great Britain and the United States, one soldier killing ten and killing a hundred.[... Now you are the warriors to go out to the front lines to defeat enemies of your own age. You are right behind the soldiers who are ahead of you. You have no idea how proud the soldiers are of this. Everyone, let's be strong!" (Shonen Kurabu March/April 1945, p. 62). 


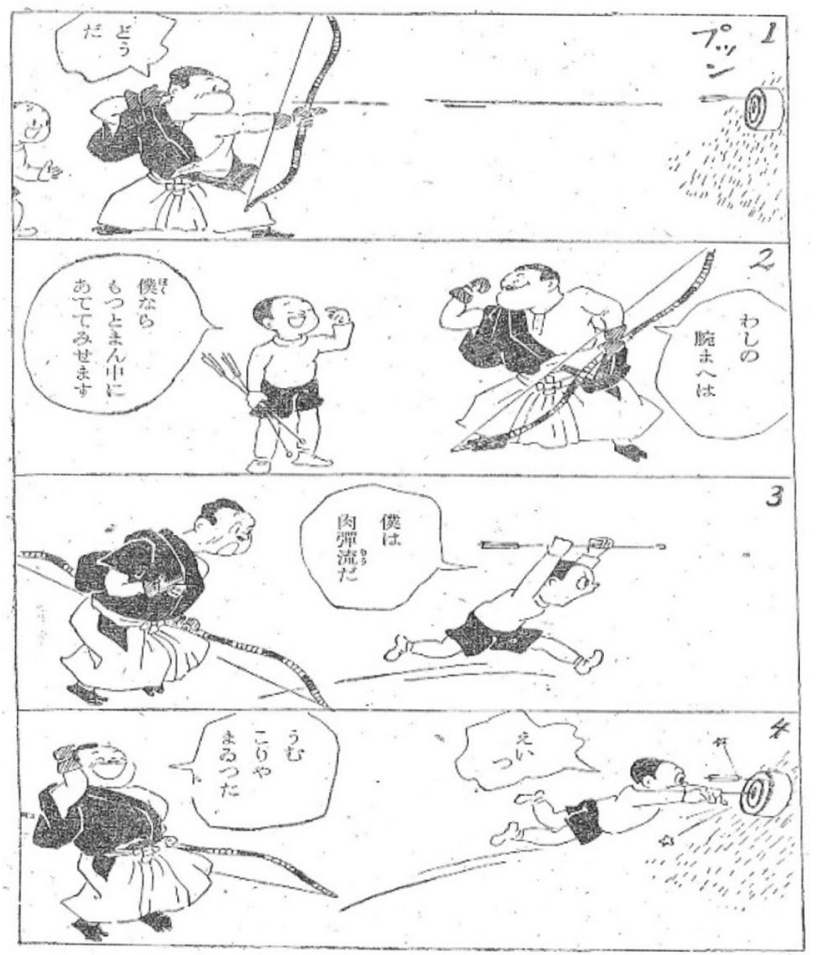

Fig. 4 “Human-Bullet Flow” Shonen Kurabu May/June 1945, p. 63

The comic strips on the following pages clearly reveal what is expected from the children. For example, the cartoon titled "Trample them to death" (Fig. 3) depicts a mother in monpe (women's work pants) smiling at her son, who has drawn the faces of Truman and Churchill on the soles of his shoes to constantly trample them with each step. The May/June issue of 1945 published a thin volume of only 31 pages, admitting to being unable to cover various contents due to the poor situation. However, the issue printed a slogan on the cover encouraging the 100 million Japanese people to fight to prove their loyalty, and the editorial department vowed to persevere for the magazine without fear of enemy bombs (Shonen Kurabu, May/June 1945, p. 31). The cartoon Human-Bullet Flow (Fig. 4), shown in this issue, symbolically represents the children's attitudes toward war: sacrifice of the body, weaponization of the body. It shows a boy watching an adult struggle to hit the mark with an arrow. He says, "I can hit the bull's-eye," and then launches his body at the target and hits the centre. The cover of the July issue (Fig. 5), the last issue before the armistice, depicts a picture of a boy wearing a headband praying for the victory of Japan. His eyes are locked in grim resolution. A poet in this issue encourages boys to live with the spirit of the pilot, regarding him as an image of the future, the spirit of one who goes into the enemy's camp to fight. 
Fig. 5 "A hundred million Japanese, let's wear a headband of unfailing victory!" Shonen Kurabu July 1945, cover

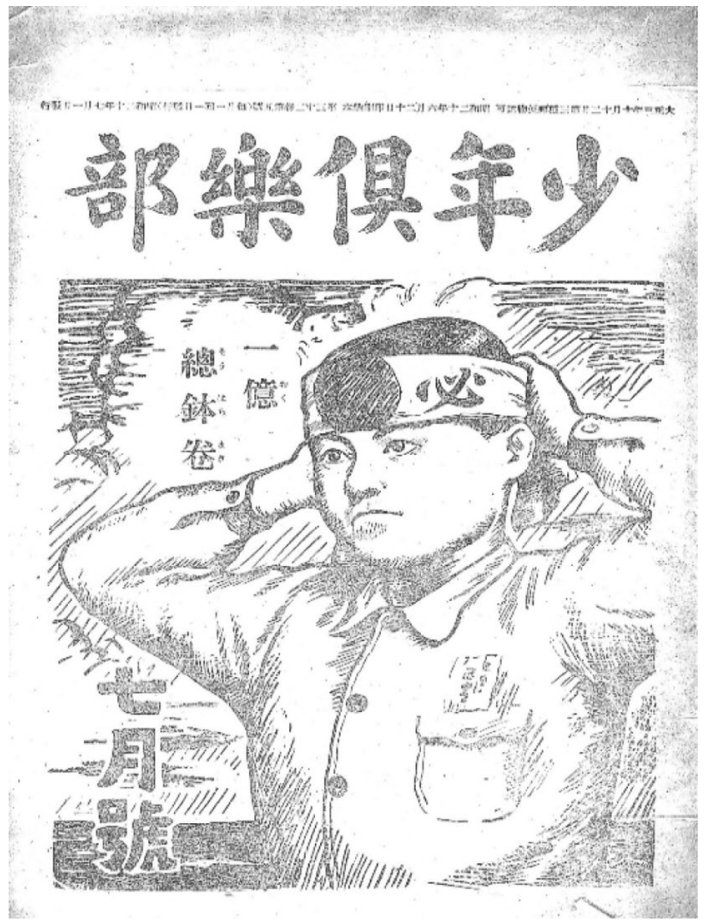

"Rise up, boy, the time is now.

Our land is indeed a battlefield.

With fierce eyes, let us charge.

The hateful enemy draws close.

Heroic, attacking ceaselessly,

The commando soars toward the base,

$\mathrm{O}$, let's follow the eagle god.

We are the boys of Japan. (...)

We are small front-line troops.

With blood sacrificed for our country,

Now defending our livelihoods,

Shining victory is ours

(Shonen Kurabu July 1945, pp. 20-21, [“Rise Up Boys”]).

Here the boys are no longer students in the classroom but have become the workers who support the war in their own workplaces. They are future "eagle 


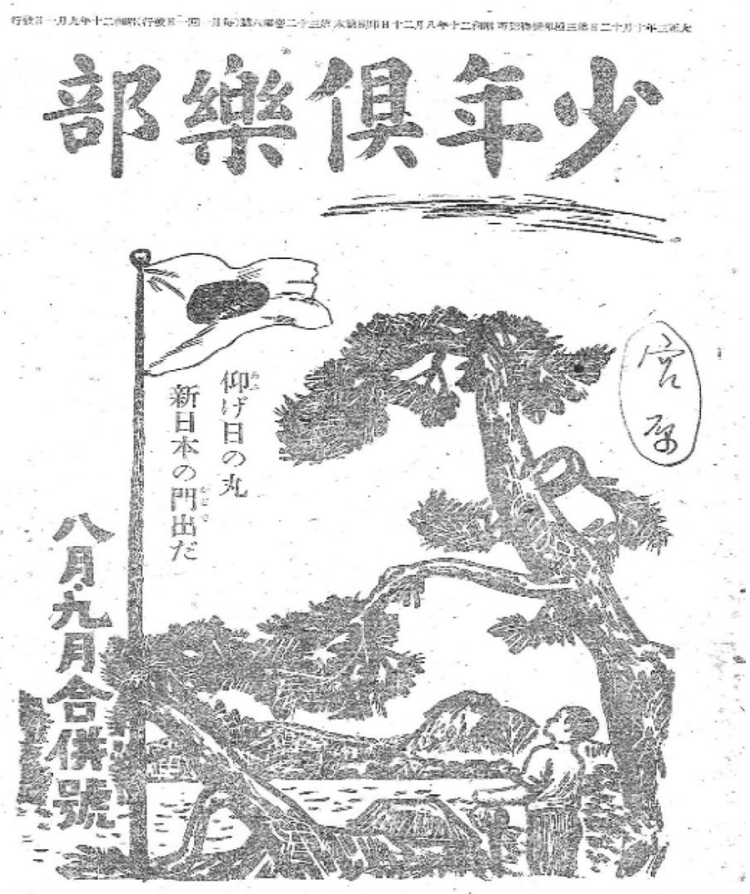

Fig. 6 "Let's turn our face upward to Hinomaru. It is a start of new Japan" Shonen Kurabu August/September 1945, cover

gods" who are to sacrifice their bodies as weapons. At the end of the war, the brave boys were becoming "gods" ready to die.

The idea of expansion into the colonial continent through war was not merely a story of people directly involved in national policy; it also spread into the lives of the masses. For example, Taku Miki, who was a child during the war, recalled: "I thought if I went to the battlefield, I would be willing to kill people for the country of Japan, for the Japanese people. ... I just wanted to become an adult quickly and fight against the bad guys who were against our Japan, and I could not fathom what that meant" (Okamoto, 1974, pp. 118-120). Hiroshi Sunada said that his dream was to enlist in the navy to become a commando (Okamoto, 1974, p. 204). During the war, hundreds of young commandos crashed into enemy warships or aircraft carriers in the Pacific Ocean and sank or set fire to them. Sunada wrote in his diary on the day he heard news of the commandos: "Today the commando aircraft take off again. It is to dedicate their life to the Great Japanese Empire and His Majesty the Emperor. We little subjects also must follow. Japan wins. It must win" (Okamoto, 1974, p. 205).

Finally, in August 1945, the Emperor of Japan declared the defeat of Japan. However, Shonen Kurabu continued publishing, with the bound volume of August and 
September, issued on September 1, 1945 (Fig. 6). The cover page read: "Let's turn our face upward to Hinomaru. It is the start of the new Japan." On the issue was printed an article written by the Emperor repenting the war. There was a photograph on two pages of the magazine, titled "Hot Tears Flowing on the Cobble Stones," which showed the Japanese people saying "We are sorry," kneeling down with tears on the hot cobble stones in the summer sunlight in front of the Imperial Palace after the declaration of defeat by the Emperor. Still thin, with 32 pages, the issue reflected the changes in the state of affairs so naturally. The contents of the magazine, which had driven the boys to become war weapons in the previous issues, listed articles for the children immediately after the defeat as follows:

The Imperial Rescript was announced and the Japanese ambassador plenipotentiary signed the Instrument of Surrender to the Allies in Tokyo Bay. The Allied Forces began to be stationed in Tokyo, but people are not disturbed at all. It seems that everyone can hear the crickets chirp tonight. It is said that, among the people who were in the battlefield, there are many now living in tents in places destroyed by fire. How do these people fare? It might be thought that all crickets and their eggs have been burnt to death in the tense flames of the attack, but the grass will grow from the ashes and some crickets will live on in the thicket. The sound of crickets heard in the ruins pierces one's heart in particular. (Shonen Kurabu August/September 1945, pp. 7-8).

In this article, the sentiments of the Japanese people after defeat are alluded to in terms of nature and the chirping of insects, expressing compassion for the Japanese and their strength to survive the ruins. The author of another article in the same issue calls out the names of boys one by one, urging them to face the new era with dignity and without losing the Japanese spirit. He concludes by advising the boys to cherish the Japanese language, behave themselves with discretion, and participate in the construction of a new Japan so that Western people would marvel at the strength of Japan. The editorial department asks the boys to read this article repeatedly (Shonen Kurabu August/September 1945, pp. 14-15).

The article about the opening of a new era never mentions the Japanese defeat in war. Instead, it says that although they may seem to have lost the battle they are never defeated. What they need is to set a new goal for victory. This approach actually eliminates a chance to register Japanese regret for the war. The magazine erases the memory of war in Japan as quickly as possible, as if the past could be deleted instantly, and directs the boys' energy to the goal of building a new society. The editor writes:

The pen feels too heavy for me who is reporting on this news. ... His Majesty the Emperor himself declared the end of the war in a broadcast. This reporter was standing to attention in front of the radio of the editorial department and listened to the Emperor deign to speak. ... The Japanese boys fought really well. You fought well to the end. Everyone clearly acknowledges this. They are deeply impressed. Whatever you think about the bitter end to this war-this reporter falls into deep reflection upon this matter, finding no time to wipe the 
Fig. 7 A boy in a straw hat. Shonen Kurabu, October 1945, Cover

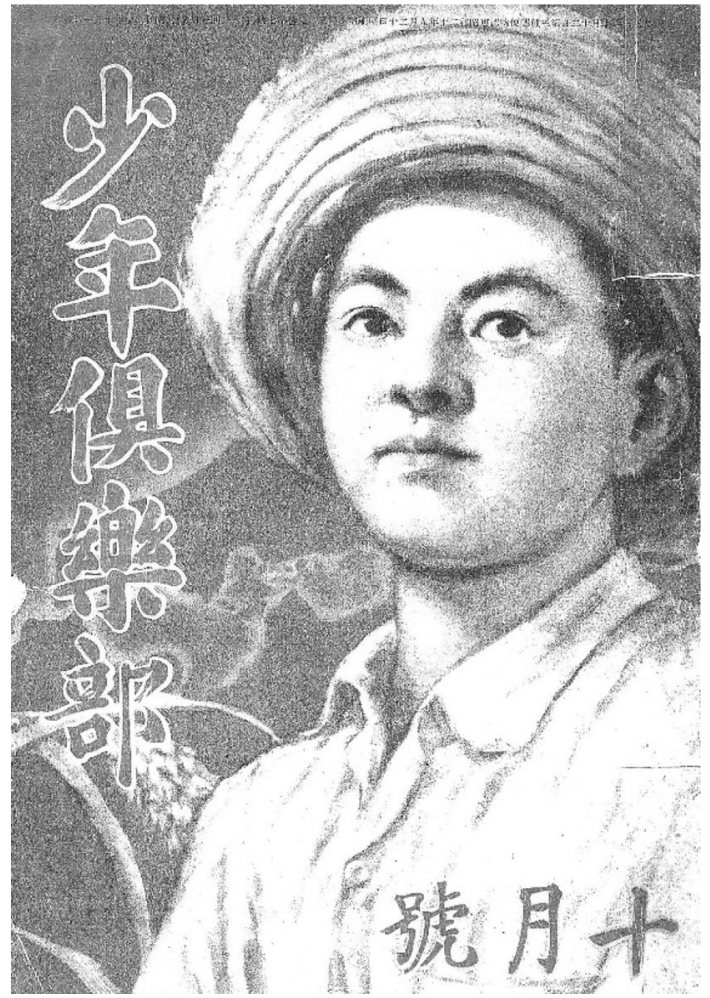

tears that run down. If only I could, I would just want to encourage each of you by patting you on the shoulder. ... You have to show the people in the world the dignified attitude of Japanese boys. I think this issue of Shonen Kurabu will be a memorial to your soul in your life. (Shonen Kurabu August/September 1945 , p. 32).

Here we can see the attitude of the Japanese toward defeat. For the pitiful Japanese, who followed the right path all along but were forced to surrender, the rhetoric naturally shifts to an appeal to not lose the Japanese spirit among the ruins, but to become subjects for the construction of a new era. This reflected the public consciousness of the time. Bombed by atomic weapons and under the jurisdiction of GHQ, the Japanese regarded themselves as victims. The wartime atrocities they committed on other peoples mostly took place outside the Japanese archipelago, and the Japanese public had to suffer economic hardship and the death of family members caused by the war. Hence the war meant pain for most Japanese people. They needed a medium to help rid themselves of a sense of defeat and to speak for the "pride of the Japanese people."

From October, the size of the magazine expanded to 50 pages. The colored cover featured a boy with a gentle expression, wearing a straw hat against a background of rice (Fig. 7). The images of boys on the covers of following issues were 
so peaceful that readers may have wondered when the war was. The emphasis never strayed from the pride of the Japanese.

You should be proud of being Japanese. For instance, some people are said to scramble to pick up caramel and chocolate sprinkled on the ground by the occupying forces as they pass by. That is very shameful behavior. It is important to have pride as a Japanese person. Needless to say, the foundation of Japan is the best in the world. It is said that the US troops are pleased that the Japanese people are obedient to the words of His Majesty the Emperor and peacefully accepted the US military. We must continue to take pride in being a boy of this great nation and strive not to undermine its pride (Shonen Kurabu October 1945, p.22).

The article titled "With the Pride of Japanese Boys" (Shonen Kurabu February 1946, p. 43) also writes that those pestering the US military for chocolate and goods are the "shame of Japanese boys." For the recovery of pride, the recovery of the proud Japanese, any mention of defeat had to be avoided.

Overcoming difficulties and becoming a good Japanese citizen became a constant topic for the magazine. The publication of the poem "Strong in the Rain" by Kenji Miyazawa (1896-1933), a famous author of children's books, made a symbolic appeal to the Japanese who were struggling through the difficulties. The magazine depicted children as the protagonists to build an ideal New Japan through articles such as "Honor of Japanese Boys Overcoming Difficulties" (Shonen Kurabu November/December 1945, p. 42) and "Bravely Marching on the New Path" (Shonen Kurabu January 1946, p. 15). The daily life of the children began to be described in the "Good Friends Newspaper" (Shonen Kurabu January 1946, pp. 44-45), in a section for children's contributions. It mostly recorded the resolutions of boys to work together for the progress of Japan, such as "Let's all gather together," "Everything will become better," "Let's overcome the hardships" and "Let's try our best" (Shonen Kurabu August 1946, p. 48).

The intention of the magazine itself, that young children should not despair and feel guilty, is understandable. Yet, what had been forced upon the children before the defeat? The magazine had treated the boys not as children to be protected by adults, but as independent individuals who must be capable of fulfilling the war mission (Seo, 2018a, pp. 230-231). They were supposed to take responsibility for this even at the expense of their own lives. Shonen Kurabu had selected winners from numerous articles that boys sent in about how hard they were striving to be "great Japanese" and listed their names and schools in every issue. Immediately after the defeat, however, all mention of war responsibility disappeared. The magazine stopped mentioning war and began to treat the readers as innocent children.

The magazine had been completely transformed, without a trace of the articles on war which had plastered the pages of the issues before the ceasefire. Instead, it urged the children to repeatedly read articles such as "Let's Not Become Shameful Japanese," "Let's Overcome Difficulties," and "Let's Become Workers for a New Japan." The child readers responded to this by re-affirming their new resolutions. 


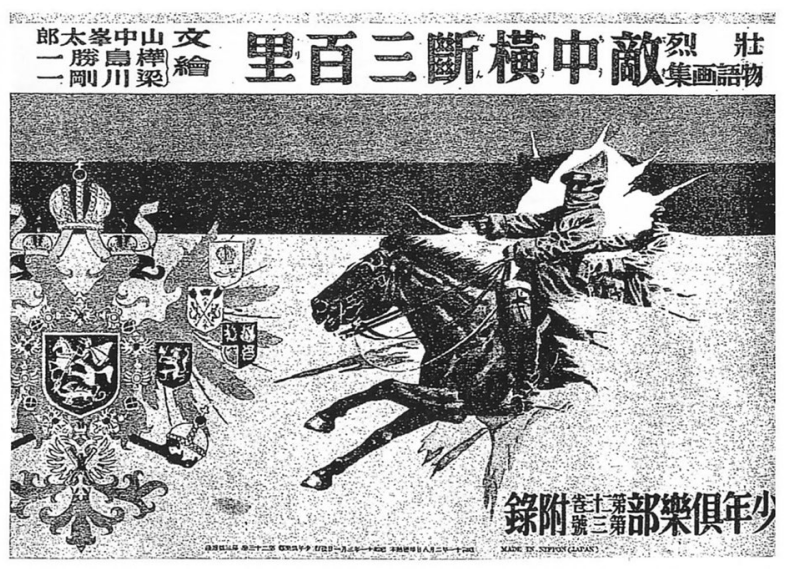

Fig. 8 Katsuichi Kabashima's pre-War drawing. Appendix of Shonen Kurabu February 1936 cover

\section{Boys Reading War Stories Again}

After the end of the war, conservative politicians, fronted by Shigeru Yoshida, seized power. Showing no repentance for Japan's invasion of Asian countries and colonial rule, they passed the responsibility to the military and faithfully cooperated with the United States so that Japan could be recognized as an ally of USA during the Cold War (Tanaka, 2000, p.13). A similar tendency is found in Shonen Kurabu.

Immediately after the defeat, the greatest change in Shonen Kurabu was an increase in the description of the US forces with whom the Japanese had to cooperate, and an increase of articles written in the Roman alphabet. "Masao's Picture Diary," a cartoon about the friendship between the US soldiers and Japanese children, was printed in both Japanese and English. Japanese pronunciation was added to anything written in English along with a glossary (Shonen Kurabu February 1946, pp. 18-19). The language of the enemy had now become a medium of cooperation.

From the period immediately after the truce and until the economic boom that came out of the Korean War in around 1950, the magazine industry of Japan was taking some time to breathe, and the circulation of Shonen Kurabu was small. There was even a notice in the May 1947 issue that all of the magazines published by Kodansha were to be reduced in size and issued bi-monthly due to the shortage of printing paper (Shonen Kurabu May 1947, p. 56).

Even at such a time, the people who kept Shonen Kurabu going were the same writers, painters and cartoonists who had been active before the defeat. Katsuichi Kabashima, who had enthralled many children with his fine pen drawings of weapons and dynamic war scenes, now changed the theme of his drawings to nature (Shonen Kurabu May 1950, Figs. 8 and 9). Also, the November 1949 issue of the magazine resumed serialization of the comic strip by Keizo Shimada. Before the defeat he had been the author of Dankichi's Adventure, which depicted colonial exploitation (Kato, 1966b, p. 913) through the advance of Japan into the Southern countries (British Malaya, Indochina, British-ruled Burma, the Dutch 
Fig. 9 Katsuichi Kabashima's post-war drawing. Shonen Kurabu May, 1950, p. 4

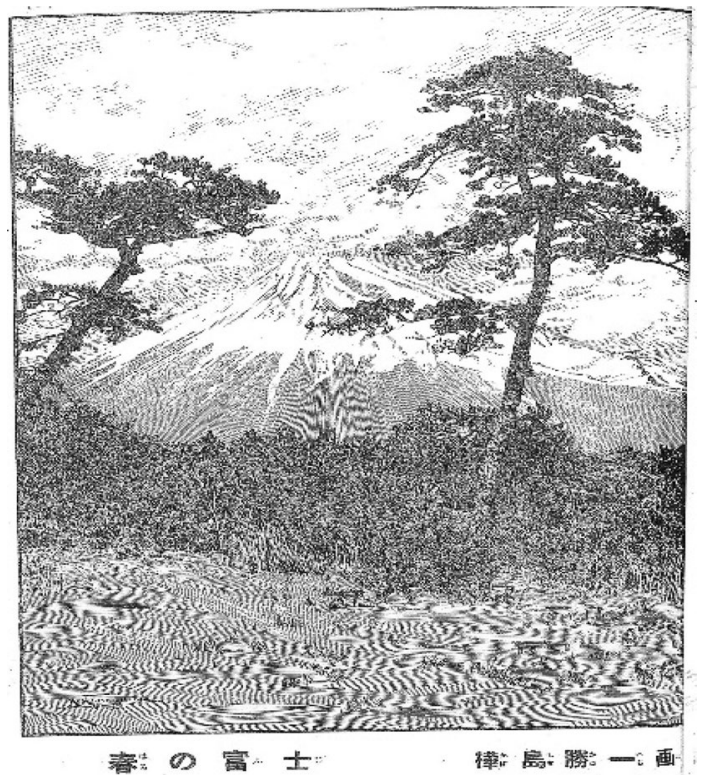

East Indies, the Philippines and Thailand). The cartoon had previously depicted Japanese people teaching culture to the ignorant indigenous people of the Southern nations. After the war, all too easily, battles turned into sports, pictures of weapons into pictures of nature, and colonization into mere adventure. Dankichi's Adventure was reprinted in November 1949, but Shimada also wrote a series about Garigong, a mouse that used to work with Dankichi and became a respectable character by doing good. Similarly, Suiho Tagawa's Norakuro, who was a warrior in his earlier comics, became a fighter for justice. During the war, the magazine's writers had consistently presented readers with the concept of "the proud Japanese who win the war." Afterwards, the magazine omitted "war" and only emphasized "the proud Japanese."

Along with the Korean War and the change of the American policy on the Far East, the pacifism that was the national policy of Japan after the end of the war collapsed, and the Japanese government turned to the expansion of armaments. As the National Safety Forces and the National Guard were reorganized into the SelfDefense Forces, the atmosphere of rearmament became prevalent in Japanese society. This atmosphere is also visible in Shonen Kurabu.

The March 1954 issue opened with a story of a war between aliens and Japan, which signaled a reappearance of the pictures of boy warriors and weapons. Pictures took up more space than the text in the story, which was about boys fighting against an alien named Phobos who attacked Japan (Shonen Kurabu March 1954, pp. 21-28). In this way, war and children were brought close to each other again. All the protagonists of the stories were boy warriors fighting for Japan. At times, the opponent of the Japanese boy warrior was depicted in vague terms as an alien or enemy, but some stories blatantly included anecdotes of Japanese soldiers who had been famous for their bravery and heroism in the Pacific War. 
The bonus for the October 1954 issue was a model of a new rifle with a cover image of a boy pilot. The issue itself was full of war stories. The story "Roaring Sound of Sinking" (Shonen Kurabu October 1954, pp. 9-17) in this issue depicted a dynamic aerial battle scene of Japanese pilots over the sea during World War II.

The November issue of the same year featured a group of boy reporters, consisting of magazine readers, visiting the Japan Self-Defense Force and taking pictures of soldiers working hard to defend their country. The photographs showed tanks, helicopters, cannons, and warships. The December issue also included airplane pictorials, warship photos, and pictures of Japanese Soldiers. The magazine published in 1955 still contained stories of boy warriors.

Less than 10 years after the end of the war, war stories had reappeared to attract boys' interest. Although it started in the form of a space war or a virtual enemy that did not exist in reality, the polarity of the "Japanese-boy-as-crusader-for-justice vs. enemy" was the same as before. Only the stage of the battle had changed, and the truth of the war became blurred under the theme of the righteous Japanese boy. Of the war stories printed in Shonen Kurabu, there was never one in which the Japanese war was not righteous. Shonen Kurabu before the defeat conveyed a message that Japanese should aim to take part in war to achieve imperialism. After the defeat, the magazine consistently encouraged the people to maintain Japanese self-esteem, avoiding mention of war or defeat.

Shonen Kurabu, which had tried to inculcate the ethic of Japanese honor since the war, discontinued publication in 1962, due to changes in the commercial environment such as the introduction of television. Later, a collected edition of previous articles appeared on the market. Between 1966 and 1969, Kodansha published a collection of Shonen Kurabu which gathered together long and short stories, poems, some talks and information pieces. The editions of the magazine between 1930 and 1933 were reproduced from 1970 to 1975 . Some adventure novels and comic strips published at that time were reproduced from 1975 to 1976 in 42 books. In 2015, small-format adventure novels republished. In addition, reminiscences and reflections on the past, written by former readers, were also printed. Most of them are pleasant memories of childhood, overlooking the unpleasant details about where the exciting war stories had directed them. In April 2002, the magazine, Modern, discussed the process of producing Shonen Kurabu, the private lives of the well-known writers, and the influence of the comic strips and appendixes.

In the early modern period and in democratic society, the Japanese public has always lived alongside popular devices that allowed them to avoid a straightforward encounter with the reality of their war. This was why the "war story of the Japanese who honorably fought to the death" was transformed into "a touching story" and spread unopposed to many parts of the world, even to Korea which was once a colony of Japan.

\section{Conclusion}

What Shonen Kurabu aspired at its foundation in 1914 was to inspire its readers to lead an immaculate life, cultivate esthetic enjoyment, dream big dreams, be courageous and faithfully uphold justice. However, this shifted into propaganda for 
victory in war, in line with national objectives. The magazine quickly gained popularity with aggressive sales marketing. The editors connected children all around the country through inviting reader participation, and closely communicated with schools through personal visits, playing movies and public contributions. It also supported teachers and parents by providing extra materials for textbooks in the form of supplements, and added adventure and fun to them, bringing a great interest to children. After the war, it offered the new task of "being great Japanese" in order to build a new Japan in the absence of reflection on and regret for the war and with no mention of responsibility.

Japanese attitudes toward war continue to contribute to the formation of the positive view of the Pacific war. Nobukatsu Fujioka's revisionist Historical Liberalism Study Group (Jiyushugi Shikan Kenkyukai) argues that Japan's imperialist invasion, colonial policy in the settlements and war crimes are overly criticized in the textbooks. This is not only a problem of what the existing right wingers believe, but contributes to the beliefs of the general population, the generations who never experienced the war, affecting their understanding of history. It results in the growth of more rightwing online groups like Netouyo. Unchallenged exposure to such views endangers the positive understanding of history which children need to have.

This study examined how Japanese understanding about the war developed through Shonen Kurabu over time; but the proper understanding of history is not only an issue for the Japanese. We need to watch out for the tendency to connect war to a sense of pleasure. In its own time, Shonen Kurabu promoted the beautification of war, and the absence of reflection or regret. This can be repeated if today's mass media, for example films and video games, generate contents that associate war only with excitement, fun and pleasure, ignoring its true nature.

Open Access This article is licensed under a Creative Commons Attribution 4.0 International License, which permits use, sharing, adaptation, distribution and reproduction in any medium or format, as long as you give appropriate credit to the original author(s) and the source, provide a link to the Creative Commons licence, and indicate if changes were made. The images or other third party material in this article are included in the article's Creative Commons licence, unless indicated otherwise in a credit line to the material. If material is not included in the article's Creative Commons licence and your intended use is not permitted by statutory regulation or exceeds the permitted use, you will need to obtain permission directly from the copyright holder. To view a copy of this licence, visit http://creativecommons.org/licen ses/by/4.0/.

\section{References}

Giordano, Ralph. (2005). The Second Fault. Trans. Kiyohiko Nagai. Tokyo: Hakusuisha.

Han, Hyunjung. (2016). Adventure Stories and Geographical Imagination in Japanese and Korean Children's Magazines. 1925-1945, Japan Forum, 28(1), 99-120.

Hujisawa, Houe. (1997). Books for Boys During the Asia-Pacific War: Collages in Shonen Kurabu during the 15-Year War. Bulletin of the Faculty of Education, 46, 1-18.

Iwahashi, Ikuro. (1988). Shonen Kurabu and Readers. Tokyo: Zo-nsha.

Jaspers, Karl. (1998). The Question of Guilt. (Die Schuldfrage). Trans. Humio Hashimoto. Tokyo: Heibonsha Library.

Karatani, Kojin. (2012). Ethics 21. Trans. Song Taewook. Seoul: Sahoepyeonglon. 
Kato, Kenichi. (1964). Launching Shonen Kurabu (Special Edition): A Record of an Editor of Popular Children's Literature. Jidoubungei, 9(3), 54-56.

Kato, Kenichi. (Ed.) (1966a). Anthology of Shonen Kurabu 1. Tokyo: Kodansha.

Kato, Kenichi. (Ed.) (1966b). Anthology of Shonen Kurabu 3. Tokyo: Kodansha.

Kato, Kenichi. (1968). The Shonen Kurabu Era: A Reminiscence of the Editor-in-Chief. Tokyo: Kodansha.

Kawahara, Kazue. (2007). The Making of the Modern View of Children in Japan. Trans. Yang Mihwa. Seoul: Somyong.

Matsudaira, Nobuhisa. (1986). The Significance of Reading Experience in the Juvenile Period: What Shonen Kurabu Gave to Boys. Annual Report of the Department of Education, Rikkyo University 30, 34-39.

Mochida, Yukio. (1994). War Responsibility and Postwar Responsibility. Kyoto: Kamogawabooks.

Okamoto, Masaharu. (1974). There Was a War When I Was a Child. Tokyo: Akane Shobo.

Saito, Michimasa. (2015). The Fateful Encounter of Kenichi Kato, the Editor-in-Chief of Shonen Kurabu, and Koroku Sato, the Popular Writer. Journal of Hirosaki University of Health and Welfare Editorial Committee, 6(1), 111-119.

Sakamoto, Kojiro. (1989). Glory of Shonen Kurabu. Sakubuntokyoiku, 40(8), 78-81.

Sato, Koichi. (1987). A Prospect of Boy Contributors to Nihon Shonen and Shonen Kurabu: The Time of Boys Writing Submissions. Bulletin of Children's Literature, 19, 64-77.

Sato, Tadao. (1959). On the Idealism of Boys: A Re-valuation of Shonen Kurabu. Science of Thought, 4(3), 15-31.

Seo, Gijae. (2018a). The Formation of the General Reader and Reader's Participation Centered around Shonen Kurabu's Issue of 'War'. Japanese Language and Literature, 78, 225-244.

Seo, Gijae. (2018b). Shonen Kurabu's Formation of Readers and the Boys in the 'Foreign Land' of Joseon. Japanese Culture Research, 68, 207-229.

Shibuya, Kiyomi. (1983). Children's War Literature that Thinks About Peace Tokyo: Ikkosha.

Shonen Kurabu. (1930-1954). Tokyo: Kodansha.

Sunada, Hiroshi. (1976). In Search of the Birth of a New Romance: The Lessons from Shonen Kurabu as a Negative Example. Japanese Children's Literature, 22(4), 38-47.

Tanabe, Hajime. (1948). The Philosophy of Confession. Tokyo: Iwanami Shoten.

Tanaka, Hiroshi. (Ed.) (2000). Memory and Oblivion: Germany and Japan, the Post-War of the Two. Trans. Yi Gyusoo. Seoul: Samin.

Tanaka, Takuya. (2013). Aspects of the Structure and Readership of the Magazine Shonen Kurabu. Kyodai Kenkyu, 11, 121-138.

Tsuboi, Hideto. (2005). Go back to the Memories of War. Tokyo: Chikuma Shobo.

Tsuzukibashi, Toshio. (1997). The Merits and Demerits of Narratives in the Novels of Shonen Kurabu. Jidoubungei, 43(5), 16-21.

Uchida, Masakatsu. (2012). The Revival of Military Masculinity Presented by Boys' Magazines: Masculinities Under the Occupation of the Allied Forces. Jenda Shigaku, 8, 75-84.

Uy, Karl Ian and Chua, Cheng. (2016). Boy Meets the World: The Worldview of Shonen Kurabu in the 1930s. Japan Forum, 28(1), 74-98.

Yamanaka, Hisashi. (2013). The History of War Culture of the 'Shokokumin'. Tokyo: Keisoshobo.

Yi, Gyusoo. (2016). The Historical Revisionism and Conservative Swing of Jaitokai. Journal of Japanology, 43, 45-72.

Publisher's Note Springer Nature remains neutral with regard to jurisdictional claims in published maps and institutional affiliations. 